\title{
FEASIBILITY STUDY OF CEMENT COMPOSITES WITH PARA WOOD PARTICLE WASTES: STRENGTH AND DURABILITY
}

\author{
P. WORAPHOT ${ }^{1^{*}}$ \\ H. ABIDENG ${ }^{1}$ \\ K.THANIYA ${ }^{2}$
}

Received: 08/11/10

Accepted: 16/03/11

\author{
${ }^{1}$ Department of Civil Engineering \\ ${ }^{2}$ Environmental Engineering Program \\ Prince of Songkla University \\ Hatyai, Songkhla, Thailand 90112
}

*to whom all correspondence should be addressed: e-mail: pworaphot@eng.psu.ac.th

\begin{abstract}
The purpose of this study was to investigate the potential use of Para wood particle wastes and cement for producing the cement composite as a new environmental friendly construction material. Strength and durability of cement composites mixed with different mix proportions of Para wood particles (PWP) were evaluated and compared with those of control samples (ordinary Portland cement). To study property degradation, the cement composite test samples were determined under different aging conditions. Three different conditioning schemes including: 1) seawater immersion at room temperature, 2) alkaline solution immersion at room temperature and 3) elevated temperatures were considered in this study. The experimental results show that the average compressive strength and elastic modulus of the cement composites mixed with PWP decreased with the increasing of PWP content. In addition, the average compressive strength of cement composites mixed with PWP aged in alkaline and salt solutions had a similar trend as cement composites with mixed PWP (normal curing). For temperature effect, the average compressive strength significantly dropped between $100^{\circ} \mathrm{C}$ and $150^{\circ} \mathrm{C}$. The experimental results present a potential use of Para wood particle waste in cement composites. Productions manufactured from these materials with the optimum content (2\% to $10 \%)$ of MPWP are acceptable for non- and structural (with low load carrying capacity) members.
\end{abstract}

KEYWORDS: Strength, Durability, Composite, Para Wood, Particles, Waste, Cement.

\section{INTRODUCTION}

Currently, the expansion of rubber tree plantations (Hevea brasiliensis, aka Para rubber trees) in South East Asia has resulted in an increase in environmental concern. Accumulation of unmanageable wastes from Para wood product industries is one of serious environmental problems for many countries such as Thailand, Vietnam, and China. These wastes still have not been widely utilized for years. Most wastes such as sawdust, bark and chipping are disposed in uncontrolled waste pits or dumped into open areas. To overcome this environmental issue, waste recycling into building and construction materials would be one of several appropriate solutions not only to the environmental problems, but also to the reduction of building material costs.

Various forms of cement composites have been investigated by many previous researches (Demirbas et al., 1998; Udoeyo et al., 2002; Corinalsesi et al., 2005; Coatanlem et al., 2006; Topçu et al., 2007; Turget 2007; Aamr-Daya et al., 2008; Ismail et al., 2009). Rubber, glass, and paper wastes are mixed with Portland cement for many concrete products. Some previous studies, the use of wood ash wastes in cementitious materials has been intensively attended for over the past years. The mechanical properties of concrete mixed with ground hazelnut shell, wood sawdust and tea wastes used as cement aggregates were investigated (Demirbas et al.,1998). The compressive strength of sawdust ash concrete indicated the same order of strength as conventional concrete at longer curing periods (Udoeyo et al., 2002). Several significant topics on cement and wood 
composites including: compatibility, methods for manufacture and durability were discussed in details (Jorge, 2004). The use of wood sawdust and limestone dust instead of fine aggregates in bricks leads to a lightweight composite as a construction material (Turget, 2007).

However, using a combination between cement and Para wood particles in the original form has not been investigated. Thus, the main objective of this study is to evaluate strength and durability under chemical solutions and elevated temperatures of the new environmental friendly construction materials as cement composites mixed with Para wood particles.

\section{MATERIALS}

In this study, Para wood particle (PWP) in its original form is used to mix with Portland cement (Type I) for cement composites. The Para wood particle is collected from Para wood dust in the surface abrasion processing of Para wood particle boards. The Para wood particle is categorized by its particle sizes into two different grades (as fine - FPWP and mixed- MPWP as shown in Figure 1).

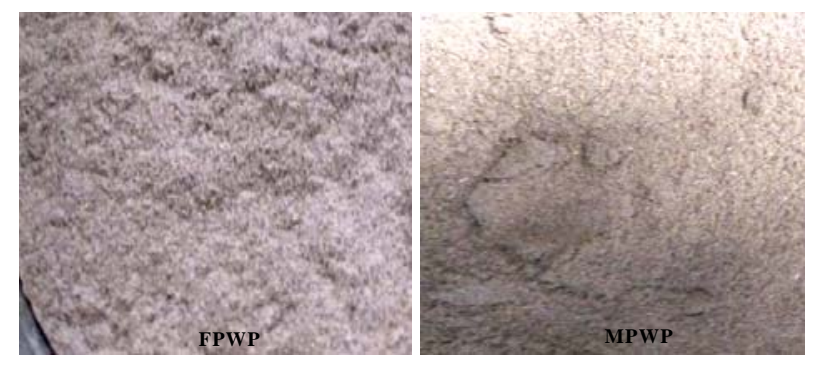

Figure 1. Fine (FPWP) and Mixed (MPWP) Para Wood Particles

The fine Para wood particles (FPWP) are characterized by its particle size up to $300 \mu \mathrm{m}$. While the mixed Para wood particles (MPWP) are classified by particle size ranging from $0 \mu \mathrm{m}$ to $1180 \mu \mathrm{m}$. The grain size distribution curve of the Para wood particle used in this study is presented in Figure 2. The cement used in this research was an ordinary Portland cement (OPC- ASTM Type I cement). Sand conforming to ASTM standard C778 was obtained from a local supplier.

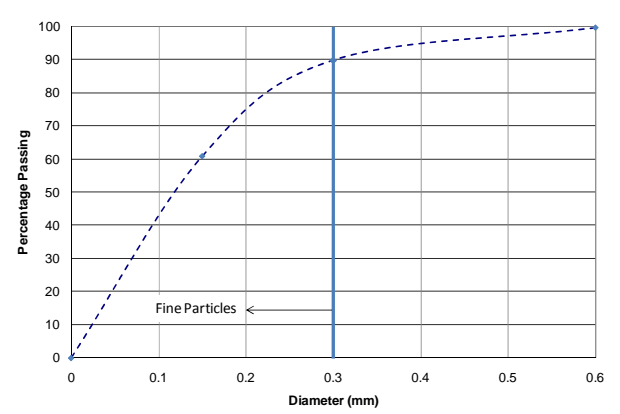

Figure 2. Grading analysis of Para wood particles

\section{PHYSICAL AND CHEMICAL PROPERTIES Of PARA-WOOD PARTICLES}

For physical properties, the average specific gravity and moisture content of Para-wood particles were found to be 1.48 and $3.16 \%$ (by weight) respectively. To determine the chemical composition of Para-wood particles, the fine and mixed particles were evaluated using chemical analysis as X-ray fluorescence spectrometry. The physical and chemical properties of Portland cement and Para wood particles used in this research are summarized in Table 1. It should be noted that Para-wood particles have the same chemical composition as original Portland cement however in different amounts. To ensure high alkalinity and hydraulic active, European Standard EN 197-1:2000 suggested that a percentage combination ratio of calcium oxide and magnesium oxide to silicon dioxide $\left(\mathrm{SiO}_{2}\right)$ exceeds one. For the results as shown in Table 1, it was found that Para-wood particles (FPWP and MPWP) used in this study are hydraulic active according to EN 197-1:2000. 
Table 1. Physical and Chemical Properties

\begin{tabular}{lccc}
\hline Physical Properties & Portland Cement & FPWP & MPWP \\
\hline Specific gravity & 3.15 & 1.62 & 1.48 \\
Moisture content (\% weight) & 0.344 & 2.67 & 3.16 \\
pH & 12 & 8 & 8 \\
Loss of ignition (\% weight) & 1.05 & 86.6 & 91.7 \\
\hline Chemical composition (\%) & Portland Cement & FPWP & MPWP \\
\hline $\mathrm{Al}_{2} \mathrm{O}_{3}$ & 2.56 & 0.28 & 0.28 \\
$\mathrm{CaO}$ & 70.85 & 17.63 & 16.05 \\
$\mathrm{SiO}_{2}$ & 11.59 & 1.10 & 1.73 \\
$\mathrm{Fe}_{2} \mathrm{O}_{3}$ & 4.40 & 0.66 & 0.76 \\
$\mathrm{MgO}$ & 1.17 & 0.93 & 0.43 \\
$\mathrm{KO}_{2}$ & 1.37 & 2.73 & 2.66 \\
$\mathrm{SO}_{3}$ & 4.2 & 0.83 & 0.82 \\
\hline
\end{tabular}

\section{TEST SAMPLES}

For this study, all test samples (mortar) with dimensions of $50 \times 50 \times 50 \mathrm{~mm}^{3}$ were prepared to satisfy the requirement of ASTM C109/109M. Seven different types of cement composite mixtures were reported as shown in Table 2. For FPWP and MPWP mixtures, the mortar samples were mixed with $2 \%, 5 \%$ and $10 \%$ (by weight) of each Para wood particle types. To study the durability of mortar samples under different aging conditions, three repeated sample sets of seven different cement composite mixtures (control, FPWP 2, FPWP 5, FPWP 10, MPWP 2, MPWP 5 and MPWP 10) were cast and wet cured for 24 hours before aging procedure.

Table 2. Proportioning of the Mortar Mixtures

\begin{tabular}{llccccc}
\hline \multirow{2}{*}{ Notation } & \multirow{2}{*}{ PWP Types } & \multicolumn{5}{c}{ Constituents (\% by weight) } \\
\cline { 3 - 7 } & & Cement & Water & Sand & PWP & Total \\
\hline Control & - & 18.9 & 12.4 & 68.7 & - & 100 \\
\hline FPWP 1 & Fine & 18.9 & 12.4 & 66.7 & 2.0 & 100 \\
\hline FPWP 2.5 & Fine & 18.9 & 12.4 & 63.7 & 5.0 & 100 \\
\hline FPWP 5 & Fine & 18.9 & 12.4 & 58.7 & 10.0 & 100 \\
\hline MPWP 1 & Mixed & 18.9 & 12.4 & 66.7 & 2.0 & 100 \\
\hline MPWP 2.5 & Mixed & 18.9 & 12.4 & 63.7 & 5.0 & 100 \\
\hline MPWP 5 & Mixed & 18.9 & 12.4 & 58.7 & 10.0 & 100 \\
\hline
\end{tabular}

\section{METHODOLOGY}

To evaluate compressive strength of cement composites mixed with Para wood particles, the compressive strength tests according to ASTM C109/109M were conducted on CONTROL compression testing machine at a loading rate of $1.5 \mathrm{~mm}$ per minute. The compressive strengths of cement composites with different mix proportions of Para wood particles were compared with the compressive strength of control samples (OPC-mortar). The compressive strengths of the test samples were measured at the ages of 7, 14, 28, 56 and 120 days. In addition, the elastic static modulus was determined using the test samples at the ages of 28 days.

To study the durability of cement composites mixed with Para wood particles, the compressive strength and property degradation were determined under different aging conditions. Three different conditioning schemes including: 1) seawater immersion at room temperature, 2) alkaline solution immersion at room temperature and 3) elevated temperatures were considered in this study. To represent seawater effect, the cement composite samples with different mix proportions of Para wood particles were immersed in salt solution at room temperature. In this study, salt solution was obtained using $97 \%$ water $\left(\mathrm{H}_{2} \mathrm{O}\right)$ and $3 \%$ Sodium Chloride $(\mathrm{NaCl})$ by weight. In addition, the cement composite samples were kept in alkaline solution at room temperature. Alkaline solution of $\mathrm{pH} \sim 13$ consisted of $97.4 \%$ water $\left(\mathrm{H}_{2} \mathrm{O}\right), 0.2 \%$ Calcium Hydroxide $\left(\mathrm{CaOH}_{2}\right), 1.4 \%$ Potassium Hydroxide $(\mathrm{KOH})$ and $1 \%$ Sodium Hydroxide $(\mathrm{NaOH})$ by weight. The cement composite samples immersed in different chemical solutions (salt and alkaline solutions) were aged for 7, 14, 28, 56 and 120 days. 
After aging procedures, the cement composite samples were prepared for compressive strength test.

In order to compare the durability under elevated temperatures of control and cement composite samples, the test samples were exposed to temperatures of $60,100,150$ and $300{ }^{\circ} \mathrm{C}$ for 3 hours. The test samples were left to be cooled at room temperature before the compressive strength tests were performed. Summary of test sample details and conditions are presented in Table 3.

Table 3. Summary of Test Sample Details and Conditions

\begin{tabular}{|c|c|c|c|c|c|c|c|}
\hline \multirow{2}{*}{$\begin{array}{c}\text { Test } \\
\text { Method }\end{array}$} & \multirow{2}{*}{$\begin{array}{c}\text { Sample } \\
\text { Types }\end{array}$} & \multirow{2}{*}{$\begin{array}{l}\text { Durability } \\
\text { Condition }\end{array}$} & \multicolumn{5}{|c|}{ Sample Age (days) } \\
\hline & & & 7 & 14 & 28 & 56 & 120 \\
\hline \multirow{6}{*}{$\begin{array}{c}\text { Compressiv } \\
\text { e } \\
\text { Strength }\end{array}$} & \multirow{6}{*}{$\begin{array}{l}\text { 1.Control } \\
\text { 2.FPWP } \\
\text { 3.MPWP }\end{array}$} & Room temperature & $\checkmark$ & $\checkmark$ & $\checkmark$ & $\checkmark$ & $\checkmark$ \\
\hline & & Seawater effect & $\checkmark$ & $\checkmark$ & $\checkmark$ & $\checkmark$ & $\checkmark$ \\
\hline & & Alkaline solution & $\checkmark$ & $\checkmark$ & $\checkmark$ & $\checkmark$ & $\checkmark$ \\
\hline & & Elevated temperatures & & & & & \\
\hline & & $(60,100,150$ and 300 & ---- & ---- & $\checkmark$ & ---- & ---- \\
\hline & & $\left.{ }^{\circ} \mathrm{C}\right)$ & & & & & \\
\hline \multirow{3}{*}{$\begin{array}{l}\text { Modulus of } \\
\text { Elasticity }\end{array}$} & 1.Control & & & & & & \\
\hline & 2.FPWP & Room temperature & ---- & ---- & $\checkmark$ & ---- & ---- \\
\hline & 3.MPWP & & & & & & \\
\hline
\end{tabular}

\section{COMPRESSIVE STRENGTH}

The compressive strength results of the test samples at the ages of $7,14,28,56$ and 120 days are presented in Table 4. The average compressive strengths of the cement composite samples mixed with Para wood particles were lower than the compressive strength of control samples. However, the average compressive strength of cement composite samples with Para wood particles indicates a trend of increase with increasing ages. It was observed that the compressive strength decreased directly with increase of the amount of Para wood particles. In addition, the decrease in compressive strength was inversely with the Para wood particle size increased. Similarly, the trend of strength reduction has been found in the previous researches (Tay, 1987; Ikpong, 1993; Udoeyo et al., 2002). The lower compressive strength of cement composites with Para wood particles (compared to the compressive strength of control samples) could be due to filler effect of Para wood particles in the cement composites. The product formed by combination of cement and Para wood particles is contributed to the lower compressive strength as compared to the hydraulic product of original Portland cement (control samples). In addition, the bonding between mortar and Para wood particles is quite low compared with that of the control samples (Zheng, et al., 2008).

Table 4. Compressive Strengths of Test Samples

\begin{tabular}{|c|c|c|c|c|c|c|}
\hline \multirow{2}{*}{ Notation } & \multirow{2}{*}{ Condition } & \multicolumn{5}{|c|}{ Average Compressive Strength (MPa) } \\
\hline & & 7-day & 14-day & 28-day & 56-day & 120-day \\
\hline Control & \multirow{7}{*}{$\begin{array}{c}\text { Room } \\
\text { Temperature }\end{array}$} & 31.52 & 36.16 & 42.79 & 44.52 & 45.39 \\
\hline FPWP 2 & & 22.22 & 25.55 & 29.73 & 31.04 & 32.13 \\
\hline FPWP 5 & & 20.57 & 23.09 & 27.21 & 28.13 & 29.96 \\
\hline FPWP 10 & & 18.86 & 22.05 & 25.31 & 27.75 & 28.83 \\
\hline MPWP 2 & & 24.25 & 31.70 & 32.25 & 33.66 & 35.49 \\
\hline MPWP 5 & & 23.83 & 30.32 & 32.15 & 32.97 & 34.43 \\
\hline MPWP 10 & & 20.49 & 30.95 & 31.67 & 32.27 & 33.61 \\
\hline
\end{tabular}

The strength relation with ages and particle content are presented in Figure 3 . The average compressive strength of cement composites with Para wood particles are ranged between $30 \mathrm{MPa}$ 
and $36 \mathrm{MPa}$. As shown in Figure 3, it seems that the optimum content of Para wood particles filled into cement composites are up to $10 \%$ (by weight) of the mixed particle type.

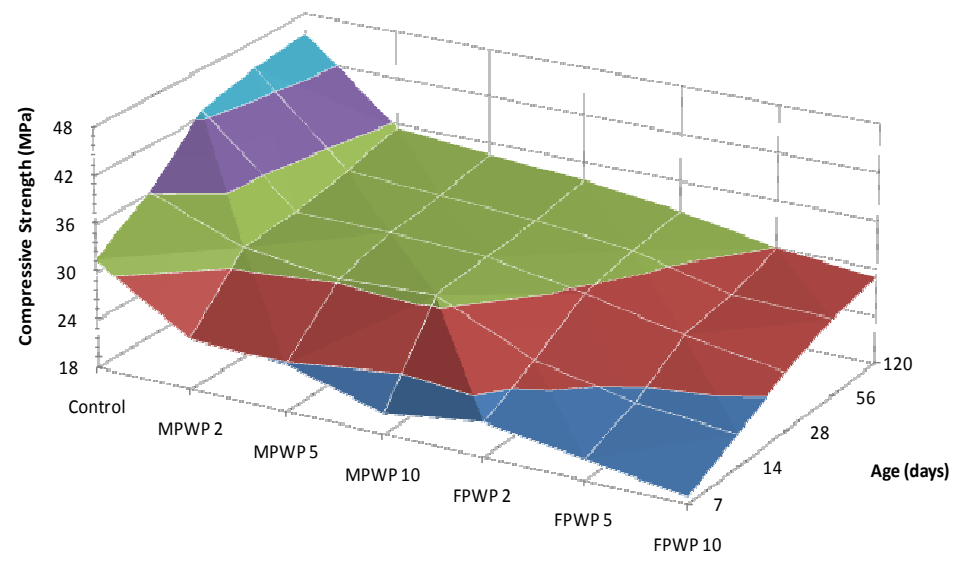

Figure 3. Strength Relations with Ages and Particle Content

The relative compressive strength of cement composites with Para wood particles based on the 28day strength comparable with those of the control samples at the same ages indicates a trend of the compressive strength development as shown in Figure 4. According to the strength development results, the increase of the Para-wood particle content serves to significantly reduce the compressive strength of the cement composites. The average compressive strength of cement composites with Para wood particles was between $60 \%$ and $78 \%$ of the control strength for all sample ages.

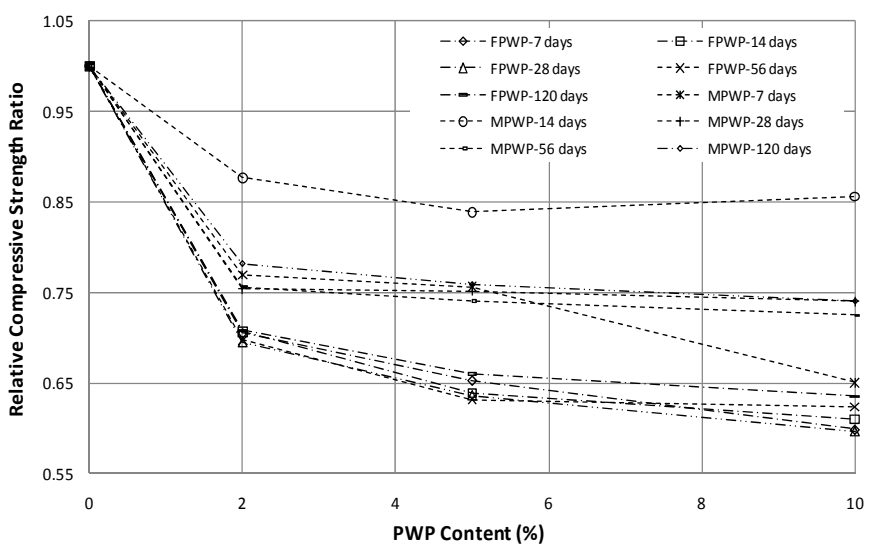

Figure 4. Relative Strength Ratios with Particle Content

\section{ELASTIC MODULUS}

For this study, the static modulus of elasticity of cement composites with Para wood particles was evaluated in accordance with ASTM C469 (ASTM 2002E1). The modulus of elasticity was conducted on the test samples at the age of 28 days. To determine the static modulus of elasticity, the slope based on the two linear points of stress-strain relation: 1) the first point at longitudinal strain $50 \mu \varepsilon$ and 2) the second point at compressive stress corresponding to $40 \%$ of ultimate load was used for this purpose. From the experimental results, typical relations between compressive stress and strain of the cement composites mixed with different Para wood particle contents are presented in Figure 5. 


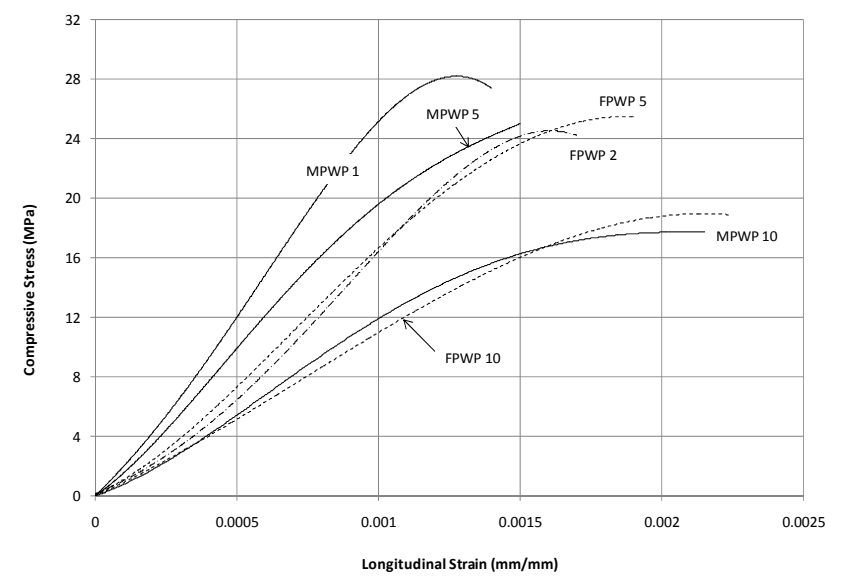

Figure 5. Typical Stress-Strain Relations of Cement Composites with PWP

The static modulus of elasticity of cement composites mixed with Para-wood particles was lower than that of the control samples (OPC). The static modulus of elasticity tends to decrease as the Para wood particle size and proportion increased. It was observed that the trend of elastic modulus was similar to that of compressive strength. The maximum reduction in the static modulus of elasticity was obtained from cement composites mixed with $10 \%$ of (fine or mixed) Para wood particles.

The static modulus of elasticity reduced from $24.9 \mathrm{GPa}$ to $11.36 \mathrm{GPa}$ corresponding to a reduction of $54 \%$. The static modulus of elasticity based on the $\mathrm{ACl}$ equation were compared with the experimental results of modulus of elasticity for cement composites mixed with Para wood particles. As shown in Figure 6, the static modulus of elasticity increases with the increase in compressive strength. Based on this experimental result, the $A C l$ elastic modulus equation $\left(E=4.73 \sqrt{ } f_{c}{ }_{c}\right)$ multiplied by reduction factor $(0.83)$ can be reasonably used to predict elastic modulus of cement composite mixed with PWP.

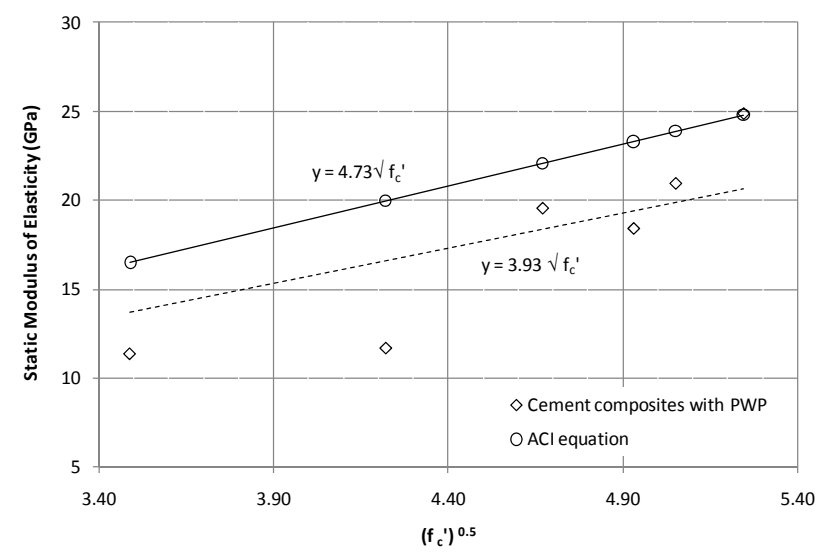

Figure 6. Comparison of Elastic Modulus ( $\mathrm{ACl}$ equation versus Experimental Results)

\section{ALKALINE SOLUTION AND SEAWATER EFFECT}

To measure durability of test samples, the compressive strength is used as an indicator in this study. In general, the stronger sample (higher compressive strength) will provide a longer life (more durable) (Pavia et al., 2008). The average compression strengths of cement composites mixed with PWP aged in alkaline solution are considerably lower than those at room temperature (Table 4) as shown in Table 5. 
Table 5. Compressive Strengths under Aging Conditions

\begin{tabular}{|c|c|c|c|c|c|c|}
\hline \multirow{2}{*}{ Notation } & \multirow{2}{*}{ Condition } & \multicolumn{5}{|c|}{ Average Compressive Strength (MPa) } \\
\hline & & 7-day & 14-day & 28-day & 56-day & 120-day \\
\hline Control & \multirow{7}{*}{$\begin{array}{l}\text { Alkaline } \\
\text { Solution }\end{array}$} & 28.85 & 31.78 & 35.87 & 36.18 & 36.73 \\
\hline FPWP 2 & & 20.30 & 23.70 & 26.85 & 27.70 & 28.75 \\
\hline FPWP 5 & & 18.21 & 22.05 & 24.16 & 24.73 & 25.40 \\
\hline FPWP 10 & & 17.73 & 20.81 & 22.26 & 22.40 & 24.06 \\
\hline MPWP 2 & & 26.02 & 25.06 & 30.82 & 32.39 & 33.11 \\
\hline MPWP 5 & & 22.72 & 25.06 & 27.18 & 28.26 & 30.05 \\
\hline MPWP 10 & & 18.98 & 22.16 & 26.34 & 26.90 & 27.50 \\
\hline Control & \multirow{7}{*}{ Seawater } & 27.53 & 28.17 & 29.09 & 30.15 & 31.36 \\
\hline FPWP 2 & & 26.08 & 26.67 & 27.30 & 28.65 & 30.83 \\
\hline FPWP 5 & & 23.63 & 24.78 & 25.82 & 26.98 & 30.10 \\
\hline FPWP 10 & & 22.67 & 24.12 & 26.59 & 28.47 & 30.77 \\
\hline MPWP 2 & & 26.94 & 27.71 & 28.33 & 29.81 & 30.34 \\
\hline MPWP 5 & & 26.67 & 27.87 & 28.34 & 29.56 & 30.26 \\
\hline MPWP 10 & & 22.75 & 26.04 & 27.50 & 29.73 & 30.00 \\
\hline
\end{tabular}

The maximum strength reduction of the test samples mixed with PWP was close to 50\% compared to the control test samples at the same ages. The average compressive strength of cement composites mixed with PWP aged in alkaline solution was observed to follow the same trend as cement composite with PWP at room temperature. According to the experimental results, the compressive strength tends to decrease as the PWP content and aging duration increased as shown in Figure 7 and 8.

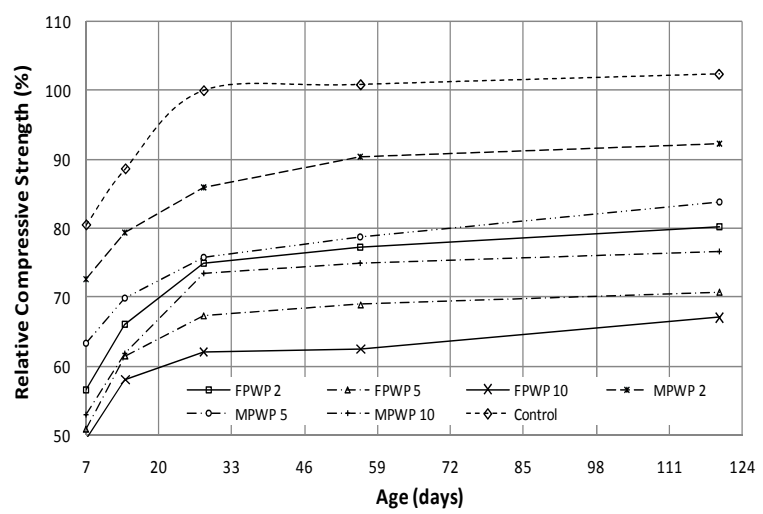

Figure 7. Relative Strength Development under Alkaline Effect

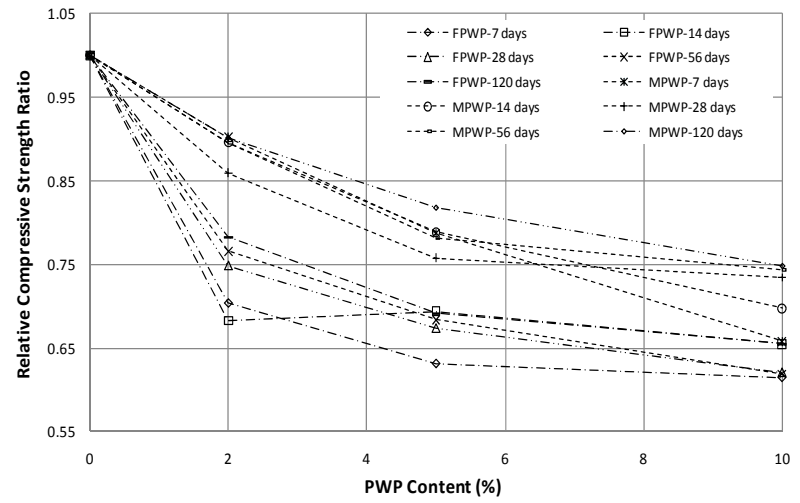

Figure 8. Relative Strength Development under Alkaline Effect

For seawater effect, the test samples were immersed under salt solution $(\mathrm{NaCl})$. The average compressive strength of the test samples are presented in Table 5. It was observed that the 
experimental results of cement composites mixed with PWP give a similar trend to those immersed under alkaline solution. In addition, the strength development of cement composites mixed with PWP was slower than that of control samples, however all the cement composites mixed with PWP at the age of 120 days attained more than $5 \%$ of the 28-day strength (control samples) as shown in Figure 9. The compressive strengths of cement composites mixed with PWP are less sensitive to the salt solution compared with alkaline effect.

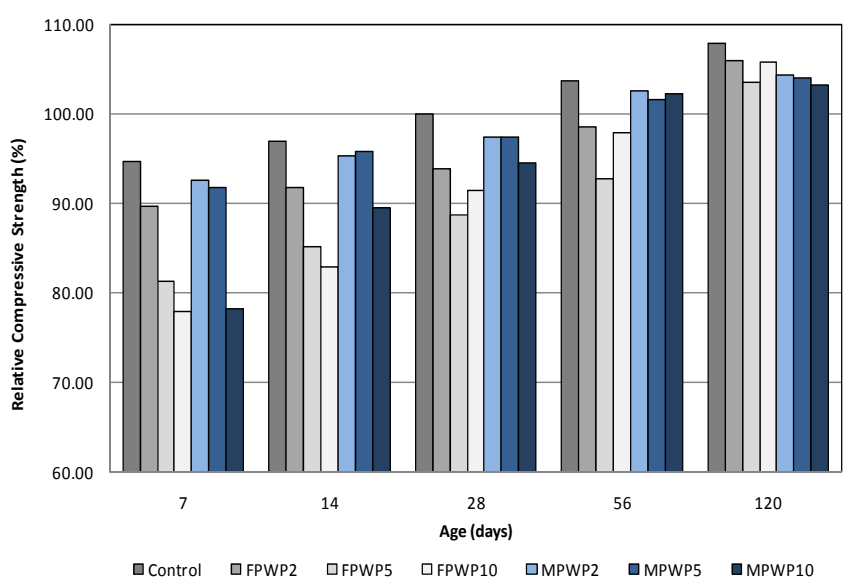

Figure 9. Relative Compressive Strengths under Seawater Effect

\section{HIGH TEMPERATURE EFFECT}

The average compressive strengths after elevated temperature exposures (at $60^{\circ} \mathrm{C}, 100^{\circ} \mathrm{C}, 150^{\circ} \mathrm{C}$ and $300^{\circ} \mathrm{C}$ for 3 hours) were presented in Table 6. It was found that the relative compressive strength (the residual strength to the strength of the control samples at $60^{\circ} \mathrm{C}$ ) for all mixtures shows a trend of reduction with increasing temperatures and PWP contents as shown in Figure 10.

Table 6. Compressive Strengths under Elevated Temperatures

\begin{tabular}{|c|c|c|c|c|c|}
\hline \multirow{2}{*}{ Notation } & \multirow{2}{*}{ Condition } & \multicolumn{4}{|c|}{ Average Compressive Strength (MPa) } \\
\hline & & $60 \mathrm{C}^{\circ}$ & $100 \mathrm{C}^{\circ}$ & $150 \mathrm{C}^{\circ}$ & $300 \mathrm{C}^{\mathrm{C}}$ \\
\hline Control & \multirow{7}{*}{$\begin{array}{l}\text { exposed to } \\
\text { temperatures } \\
\text { for } 3 \text { hours }\end{array}$} & 27.37 & 25.15 & 20.50 & 12.69 \\
\hline FPWP 2 & & 26.83 & 24.74 & 16.13 & 9.20 \\
\hline FPWP 5 & & 26.20 & 23.12 & 15.32 & 7.61 \\
\hline FPWP 10 & & 23.47 & 22.82 & 10.62 & 6.36 \\
\hline MPWP 2 & & 26.61 & 24.62 & 14.30 & 5.24 \\
\hline MPWP 5 & & 26.25 & 24.34 & 13.71 & 4.71 \\
\hline MPWP 10 & & 22.81 & 22.34 & 12.75 & 4.30 \\
\hline
\end{tabular}

The strength reduction varied between $0 \%$ and $18 \%$ of the control sample strengths at the temperature below $100^{\circ} \mathrm{C}$. Then, the average compressive strength significantly dropped between $100^{\circ} \mathrm{C}$ and $150^{\circ} \mathrm{C}$. At the temperature $150^{\circ} \mathrm{C}$, the strength reduction varied from $40 \%$ to $60 \%$ of the control sample strength at $60^{\circ} \mathrm{C}$. Beyond $150^{\circ} \mathrm{C}$, the average compressive strength continued to moderately decrease with temperature increased. The maximum strength reduction was found to be $85 \%$ for cement composites (MPWP5). 


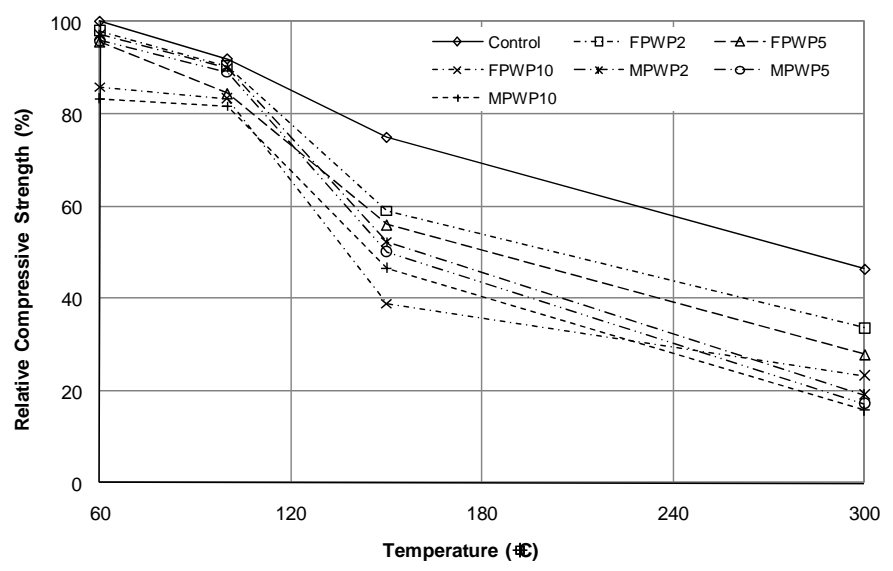

Figure 10. Relative Compressive Strengths under Elevated Temperature

\section{CONCLUSIONS}

This study investigates the feasibility of the cement composites mixed with Para wood particles to produce the new environmental friendly construction materials. The research has focused on the strength and durability of the cement composites mixed with PWP. Based on the experimental results and analytical investigations, the following summaries and conclusions are dawn:

- The average compressive strength and elastic modulus of the cement composites mixed with PWP decreased with the increasing of PWP content. At the same PWP content and ages, the compressive strength was reduced with the Para wood particle size decreased. The Para wood particles having mixed particle size provided the higher compressive strength.

- The static modulus of elasticity provided by $\mathrm{ACl}$ overestimates the elastic modulus of the cement composites mixed with PWP for $17 \%$ to $20 \%$.

- The average compressive strength of cement composites mixed with PWP aged in alkaline and salt solutions had a similar trend as cement composite with mixed PWP (normal curing). The strength developments of cement composites mixed with PWP were more sensitive to the effect of alkaline immersion compared with seawater effect.

- For all mixtures of cement composites, the average compressive strengths showed significant losses at the temperature above $100^{\circ} \mathrm{C}$.

- Although adding Para wood particles in cement composites have negative effects on the strength and durability, the experimental results still present a potential for the use of Para wood particle waste in cement composites. Productions manufactured from these materials with the optimum content (2\% to $10 \%)$ of MPWP are acceptable for non- and structural (with low load carrying capacity) members.

\section{ACKNOWLEDGEMENTS}

The authors would like to thank Sustainable Waste Management Research Team and STRuctural Engineering and Applied Mechanics (STREAM) Group, Department of Civil Engineering, Prince of Songkla University for funding support.

\section{REFERENCES}

Aamar-Daya E., Langlet T., Benazzouk A, Queneudec M., (2008), Feasibility study of lightweight cement composite containing flax by product particles: Physico-mechanical properties. Cement and Concrete Composites, 30(10), 957-963.

American Society for Testing and Materials, (2008), Standard test method for compressive strength of hydraulic cement mortars (using 2-in (or 50 mm) cube specimens). ASTM C109/109M, Annual Book of ASTM Standards.

American Society for Testing and Materials, (2006), Standard specification for standard sand. ASTM C778, Annual Book of ASTM Standards. 
American Society for Testing and Materials, (2002E1), Standard test method for static modulus of elasticity and Poisson's ratio of concrete in compression. ASTM C469, Annual Book of ASTM Standards.

Coatanlem P., Jauberthie R., Rendell F., (2006), Lightweight wood chipping concrete durability, Construction and Building Materials, 20(9), 776-781.

Corinaldesi V., Gnappi G., Moriconi G., Montenero A., (2005), Reuse of ground waste glass as aggregate for mortars, Waste Management, 25(1), 197-201.

Demirbas A., Aslan A., (1998), Effects of ground hazelnut shell, wood and tea waste on the mechanical properties of cement, Cement and Concrete Research, 28(8), 1101-1104.

European Standard. (2000), Cement composition, specifications and conformity Criteria for common cements, EN 197-1.

Ikpong A.A., (1993), The relationship between the strength and nondestructive parameters of rice husk ash concrete, Cement and Concrete Research, 23(2), 387-398.

Ismail Z.Z., Al-Hashmi E.A., (2009), Recycling of waste glass as partial replacement for fine aggregate in concrete, Waste Mangement, 29(2), 655-659.

Jorge F.C., Pereira C., Ferreira J.M.F., (2004), Wood cement composites: a review, European Journal of Wood and Wood Products, 62(5), 370-377.

Pavia S., Condren E., (2008), Study of the durability of OPC versus GGBS concrete on exposure to silage effluent, Journal of Materials in Civil Engineering, 20(4), 313-320.

Tay, J.H., (1990), Ash from oil-palm waste as concrete material, Journal of Materials in Civil Engineering, 2(2), 94-105.

Topçu I.B., Demir A., (2007), Durability of rubberized mortar and concrete, Journal of Materials in Civil Engineering, 19(2), 173-178.

Turget P., (2007), Cement composites with limestone dust and different grades of wood sawdust, Building and Enviroment, 42(11), 3801-3807.

Udoeyo F.F., Dashibil P.U., (2002), Sawdust ash as concrete material, Journal of Materials in Civil Engineering, 14(2), 173-176.

Zheng L., Huo S.X.,Yuan Y., (2008), Strength, modulus of elasticity and brittleness index of rubberized concrete, Journal of Materials in Civil Engineering, 20(11), 692-699. 